\title{
The effects of $\mathrm{pH}$ on the interaction between capsaicin and the vanilloid receptor in rat dorsal root ganglia neurons
}

\author{
*,1,2 L.M. McLatchie \& ${ }^{1}$ S. Bevan
}

\author{
${ }^{1}$ Novartis Institute for Medical Sciences, 5 Gower Place, London, WC1E 6BN
}

\begin{abstract}
1 The vanilloid receptor of sensory neurons is a polymodal nociceptor sensitive to capsaicin, protons, heat and anandamide. Although it is known that interaction occurs between these different mediators the mechanism by which this occurs is poorly understood. In this study capsaicin elicited currents were recorded from vanilloid receptors found in adult rat isolated dorsal root ganglia (DRG) neurons under conditions of varying $\mathrm{pH}$ and the mechanism whereby protons can modulate this capsaicin response investigated.

2 Under whole-cell voltage clamp, modulating extracellular $\mathrm{pH}$ shifted the position of the capsaicin $\log \left(\right.$ concentration)-response curve. Acidification from $\mathrm{pH} 9.0$ to $\mathrm{pH} 5.5$ lowered the $\mathrm{EC}_{50}$ values from $1150 \pm 250 \mathrm{nM}$ to $5 \pm 2 \mathrm{nM}$ with coincident change in the mean apparent slope factor from $2.3 \pm 0.3$ to $0.9 \pm 0.2$ and no change in maximal response.

3 The magnitude of the potentiation seen on reducing extracellular $\mathrm{pH}$ was not significantly affected by changes in extracellular calcium and magnesium concentration.

4 The response to capsaicin was not potentiated by a reduction in intracellular $\mathrm{pH}$ suggesting a site of action more accessible from the extracellular than the intracellular side of the membrane.

5 Potentiation by low $\mathrm{pH}$ was voltage independent indicating a site of action outside the membrane electric field.

6 At the single channel level, reducing extracellular $\mathrm{pH}$ increased channel open probability but had no significant effect on single channel conductance or open time.

7 These results are consistent with a model in which, on reducing extracellular $\mathrm{pH}$, the vanilloid receptor in rat DRG neurons, changes from a state with low affinity for capsaicin to one with high affinity, coincident with a loss of cooperativity. This effect, presumed to be proton mediated, appears to involve one or more sites with $\mathrm{pK}_{\mathrm{a}}$ value 7.4-7.9, outside the membrane electrical field on an extracellularly exposed region of the receptor protein.

British Journal of Pharmacology (2001) 132, 899-908
\end{abstract}

Keywords: Capsaicin; $\mathrm{pH}$; sensory neuron; vanilloid receptor; dorsal root ganglia

Abbreviations: AMPSO, 3-[(1,1-Dimethyl-2-hydroxyethyl0amino]-2-hydroxypropanesulphonic acid; ASIC, Acid sensing Ionic channel; BAPTA, 1,2-bis(2-Aminophenoxy)ethane-N, $, \mathbf{N}^{\prime}, \mathrm{N}^{\prime}$-tetraacetic acid; DMSO, Dimethyl Sulphoxide; DRG, Dorsal Root Ganglia; MES, 2-[N-Morpholino]ethanesulphonic acid; NGF, Nerve Growth Factor; VR1, Vanilla receptor 1

\section{Introduction}

Capsaicin (8-methyl-N-vanillyl-6-nonenamide), the pungent component of hot chilli peppers excites a subset of primary afferent neurons. This excitation is thought to be mediated by the activation of a ligand-gated non-selective cation channel with subsequent membrane depolarization and action potential generation (reviewed by Bevan \& Docherty, 1993). Indeed, such a channel, VR1, has been cloned (Caterina et al., 1997) and found to be expressed in sensory neurons (Caterina et al., 1997; Helliwell et al., 1998; Tominaga et al., 1998). When heterologously expressed in mammalian cells or Xenopus oocytes, VR1 also confers sensitivity to heat (Caterina et al., 1997) and to the endogenous lipid, anandamide (Zygmunt et al., 1999; Smart et al., 2000). The vanilloid receptor is therefore clearly polymodal and

\footnotetext{
*Author for correspondence; E-mail: Linda.McLatchie@kcl.ac.uk

${ }^{2}$ Current address: Centre for Cardiovascular Biology and Medicine, Cardiovascular Research, The Rayne Institute, St. Thomas' Hospital, Lambeth Palace Road, London SE1 7EH.
}

interactions between the different mediators are likely to be an important part of its function.

Changes in extracellular $\mathrm{pH}$ from the usual value of about 7.4 can be caused by a variety of physiological and pathophysiological conditions including, tissue inflammation and ischaemia (Uchida \& Murao, 1975; Jacobus et al., 1977; Steen et al., 1995). Although these changes are usually only fairly small, values below $\mathrm{pH} 6.0$ have been measured (Jacobus et al., 1977). In psychophysical studies intradermal injection or infusion of solution at $\mathrm{pH} 6.2$ is sufficient to cause pain (Lindahl, 1962; Steen \& Reeh, 1993). These effects are thought to be mediated via activation and sensitization of nociceptive and some visceral afferent fibres (Steen et al., 1992). In a sub-population of isolated DRG neurons acidification activates at least two different types of cation channel, resulting in a fast rapidly-inactivating current, which may be followed by a slower more slowly-inactivating one (Bevan \& Yeats, 1991). Recently, several proton activated channels (e.g. ASIC 1a and 3) with a variety of properties 
and kinetics have been cloned and their mRNA shown by in situ hybridization to be present in sensory ganglia (Waldmann et al., 1997a,b; Linguelis et al., 1997). In addition to these specific proton activated channels there is evidence that some of the effects seen on acidification of DRG neurons are mediated via the capsaicin receptor itself (Bevan et al., 1993; Tominaga et al., 1998). Indeed, studies in transgenic mice lacking the VR1 receptor demonstrate a loss of the more slowly-inactivating, sustained, $\mathrm{pH}$-induced current in DRG neurons, coincident with a loss of capsaicin sensitivity (Caterina et al., 2000; Davies et al., 2000).

In addition to a direct effect on sensory neurons, protons also exert a modulatory role on the capsaicin response whereby low $\mathrm{pH}$ substantially potentiates the amplitude of responses to sub-maximal concentrations of capsaicin in DRG and Trigeminal neurons (Petersen \& LaMotte, 1993; Martenson et al., 1994; Kress et al., 1996), and in cells expressing cloned VR1 (Caterina et al., 1997; Tominaga et al., 1998; Smart et al., 2000). Studies on the cloned VR1 receptor have demonstrated a shift in the capsaicin $\log$ (concentration)-response curve corresponding to a 2-6 fold increase in capsaicin affinity on decreasing $\mathrm{pH}$ from 7.4 to $\mathrm{pH}$ 6.4. A detailed, quantitative analysis of $\mathrm{pH}$ modulations of the capsaicin responses of native receptors in DRG neurons is, however, lacking. Protons interact with sites on extracellular regions of the protein (Tominaga et al., 1998; Jung et al., 1999) and site directed mutagenesis studies have identified residues in the region linking the extracellular aspect of the fifth transmembrane domain to the putative pore forming region that are important for VR1 activation by acid solutions and for potentiation of heat responses by protons (Jordt et al., 2000). The mechanisms underlying the potentiation are, however, unclear. It has yet to be resolved whether acid-induced potentiation is identical for the native receptor and for cloned VR1 and whether potentiation is similar for chemical and thermal stimuli.

In this study we have addressed these issues by studying the native vanilloid receptor in DRG neurons isolated from adult rats under whole cell voltage clamp and at the single channel level to look at affects on single channel conductance. The results represent the first comprehensive study of the mechanism of potentiation of the capsaicin response by protons and provide evidence that this effect represents an allosteric modulation affecting the transition between open and closed states of the receptor. A model is proposed based on these observations.

A preliminary account of some of this work has been reported (McLatchie \& Bevan, 1998a,b).

\section{Methods}

\section{Preparation of cells}

Dorsal root ganglion (DRG) neurons were isolated from adult male Sprague-Dawley rats by methods similar to those described previously (Bevan \& Winter, 1995). Briefly, ganglia from all levels of the spinal cord were dissected from rats of $\sim 180 \mathrm{~g}$ killed by over exposure to $\mathrm{CO}_{2}$ (according to a Home Office approved procedure). Ganglia were placed in Ham's Nutrient mix F14 (GIBCO) to which was added Ultraser-G artificial serum (4\%), L-glutamine (1 mM), penicillin $\left(50 \mathrm{IU} \mathrm{m}^{-1}\right)$ and streptomycin $\left(50 \mu \mathrm{g} \mathrm{ml}^{-1}\right)$. They were digested in collagenase (Worthington type IV $0.125 \%$ ) for $2-3 \mathrm{~h}$ before mechanical dissociation, filtering $(90 \mu \mathrm{m}$ pore) and spinning through $15 \%$ BSA to remove debris and myelin. Neurons were then resuspended in F14 media as above, with addition of nerve growth factor (NGF, $\left.50 \mathrm{ng} \mathrm{ml}^{-1}\right)$, and plated on polyornithine coated culture dishes $(35 \mathrm{~mm})$. They were incubated at $37^{\circ} \mathrm{C}$ in a humidified incubator with $3 \% \mathrm{CO}_{2}$ in air, for $16 \mathrm{~h}-4$ days before use, usually being replated $1-8 \mathrm{~h}$ before recording, to remove neurites, which may compromise the space clamp of the neurons.

\section{Electrophysiological recording}

Whole cell recordings were made from small to medium sized neurons (capacitance $42 \pm 1 \mathrm{pF}$, diameter $29.6 \pm 0.8 \mu \mathrm{m}$ $(n=217))$ without obvious neurites. Borosilicate glass patch pipettes $\left(2-6 \mathrm{M} \Omega\right.$ ) were filled with $(\mathrm{mM}): \mathrm{KCl} 140, \mathrm{CaCl}_{2}$, EGTA/2 10, MgATP 1 (or $\mathrm{MgCl}_{2} / 10$ 1,2-bis(2-Aminophenoxy)ethane-N,N, $\mathrm{N}^{\prime}, \mathrm{N}^{\prime}$-tetraacetic acid (BAPTA)), HEPES 10 , $\mathrm{pH} 7.4(\mathrm{KOH})$. One hundred $\mathrm{mM} \mathrm{CsCl}$ and $30 \mathrm{~mm} N$-methyl glucamine replaced $\mathrm{KCl}$ in experiments in which responses were studied at positive membrane potentials (shown in Figures 2, 3, 6, 7, 8). For the experiments in Figure 5 where internal $\mathrm{pH}$ was modified, $\mathrm{N}$-methyl glucamine was substituted with buffer to give a final buffer concentration of $40 \mathrm{~mm}$ whilst maintaining osmolarity. For these experiments neurons were left for at least $5 \mathrm{~min}$ after reaching the wholecell configuration before recordings were made to allow time for exchange of internal solution and neurons were only used if the series resistance was $8 \mathrm{M} \Omega$ or under. The culture dishes were continually perfused $\left(3 \mathrm{ml} \mathrm{min}{ }^{-1}\right)$ with either standard bath solution $(\mathrm{mM})$ : $\mathrm{NaCl} 140, \mathrm{KCl} 5$, glucose 10 , buffer 10 (MES (2-[N-Morpholino] ethanesulphonic acid); $\mathrm{pH}$ 5.5-6.6, HEPES, pH 7.0-7.8, AMPSO (3-[(1,1-Dimethyl-2-hydroxyethyl0amino]-2-hydroxypropanesulphonic acid); $\mathrm{pH} 8.2-$ 9.0), $\mathrm{CaCl}_{2} 2, \mathrm{MgCl}_{2}$ 1, $\mathrm{pH} 7.4(\mathrm{NaOH})$ ), or for experiments studying the current-voltage relation (Figure 6), with a modified solution to minimize potassium currents (mM): $\mathrm{NaCl} 130$, glucose 10, HEPES 10, CsCl 1, $\mathrm{CdCl}_{2} 200 \mu \mathrm{M}$, TEA $10 \mathrm{~mm}, \mathrm{MgCl}_{2}$ 3, pH $7.4(\mathrm{NaOH})$. Capsaicin (Sigma) was applied rapidly by means of a U-tube (Fenwick et al., 1982). $\mathrm{CaCl}_{2}$ and $\mathrm{MgCl}_{2}$ were replaced by $\mathrm{NaCl}$ in some experiments. Experiments were carried out at room temperature $\left(17-25^{\circ} \mathrm{C}\right)$. To avoid the introduction of any temperature related effects, $\mathrm{pH}$ comparisons were either made on individual neurons (Figures 1, 3b,c, 6, 7, 8), between comparable numbers of neurons recorded on the same day (Figures 4, 5) or, using a randomized $\mathrm{pH}$ order and repeated measurements (Figures 2, 3a). Only one neuron was used from each dish to minimize desensitization. In experiments in which a neuron was exposed to more than one $\mathrm{pH}$ value experiments were bracketed (i.e. 1st $\mathrm{pH}, 2 \mathrm{nd} \mathrm{pH}$, 1st $\mathrm{pH}$ again) and/or the order of $\mathrm{pH}$ presentation was reversed between experiments.

With the exception of Figure 1 where the response to low $\mathrm{pH}$ alone is shown, the current elicited by $\mathrm{pH}$ change alone was either subtracted or in the case of capsaicin $\log$ (concentration)-response curves at a constant $\mathrm{pH}$ the neuron was equilibrated at that $\mathrm{pH}$ value prior to capsaicin exposure. This means that all currents described are capsaicin rather 
than $\mathrm{pH}$ activated. Responses to $\mathrm{pH}$ alone required for subtraction were always obtained prior to any capsaicin exposure to avoid problems associated with persistence of capsaicin in the membrane. Capsaicin $\log$ (concentration)response curves responses were obtained by increasing rather than decreasing capsaicin concentration for the same reason. All solutions contained $0.1 \%$ dimethyl sulphoxide (DMSO) as a solvent for capsaicin; 10 and $30 \mu \mathrm{M}$ capsaicin solutions contained 1 and 3\% DMSO respectively.

\section{Data analysis}

Recordings were made with an Axoclamp 200A amplifier, filtered at $5 \mathrm{kHz}$ (unless otherwise stated) and analysed using pClamp6 software (Axon instruments). Statistical tests: ANOVA with post hoc Bonferroni and paired $t$-tests were used. All errors are standard errors of the mean.

\section{Results}

Figure 1 shows the effect of reducing the extracellular $\mathrm{pH}$ on the capsaicin-elicited current recorded from a DRG neuron held at $-60 \mathrm{mV}$. Low $\mathrm{pH}$ solution was initially applied in the absence of capsaicin to measure the small response to low $\mathrm{pH}$ alone (Figure 1a). The neuron was then exposed to either a low $(10 \mathrm{nM})$ or high $(10 \mu \mathrm{M})$ concentration of capsaicin, as indicated, first at physiological $\mathrm{pH} 7.4$ and then at $\mathrm{pH}$ 6.0. In the presence of the lower capsaicin concentration (Figure 1b), there was a large increase in current on reducing the $\mathrm{pH}$, this increase being much greater than the current elicited by the low $\mathrm{pH}$ alone, indicating a potentiation of the capsaicin evoked current (Petersen \& Lamotte, 1993; Martensen et al., 1994; Kress et al., 1996; Caterina et al., 1997). A smaller degree of potentiation was seen at the higher concentration of capsaicin (Figure 1c). This difference was not simply the result of some reduction in potentiation with time as a larger degree of potentiation was again seen on reapplication of the lower capsaicin concentration (Figure 1d).

To examine this phenomenon of potentiation further, full $\log$ (concentration)-response curves to capsaicin were constructed. A potential of $+60 \mathrm{mV}$ was used to minimize the effects of desensitization (Yeats et al., 1992; Bevan \& Docherty, 1993; Liu \& Simon, 1996) and each neuron was equilibrated for several minutes at the test extracellular $\mathrm{pH}$ before application of capsaicin at that $\mathrm{pH}$. The results for three $\mathrm{pH}$ values are shown in Figure 2a. Data from individual neurons were normalized to the current elicited by $10 \mu \mathrm{M}$ capsaicin, at that $\mathrm{pH}$, to allow for comparison of the curves. A comparison of response amplitude was made later (see below). The effect of reducing $\mathrm{pH}$ was to shift the position of the $\log$ (concentration)-response curve to the left corresponding to an increase in the apparent affinity for capsaicin. The $\mathrm{pH}$ dependence of the concentration of capsaicin required for a half maximal effect is plotted in Figure $2 b$. The curve fitted, which gives a good description of these data, assumes a shift on reducing $\mathrm{pH}$, from a low affinity state $\left(\mathrm{EC}_{50}\right.$ value $\left.1270 \pm 160 \mathrm{nM}\right)$ to a high affinity state of the receptor $\left(\mathrm{EC}_{50} 4.5 \pm 1.7 \mathrm{nM}\right)$ with a $\mathrm{pK}_{\mathrm{a}}$ value of $7.9 \pm 0.2$ determining the relative ratios of the two forms. In addition, as seen in Figure $2 \mathrm{a}$, reducing extracellular $\mathrm{pH}$ caused a reduction in the mean apparent slope factors of the individual $\log$ (concentration)-response curves to capsaicin from $2.3 \pm 0.3$ (at $\mathrm{pH} 9.0$ ) to $0.9 \pm 0.2$ (at $\mathrm{pH} 5.5$ ). The apparent slope factors, were plotted as a function of $\mathrm{pH}$, in Figure 2c. These pooled data were fitted with a curve assuming the same type of model as that in Figure $2 b$ yielding maximum and minimum values of $2.3 \pm 0.2$ and $1.1 \pm 0.2$ respectively and $\mathrm{pK}_{\mathrm{a}}$ value of $7.4 \pm 0.4$. The reduction in slope factor from a value close to 2 at high $\mathrm{pH}$ to one close to 1 at lower extracellular $\mathrm{pH}$ suggests that the capsaicin interaction with its receptor shifts from being cooperative (whereby binding of the first capsaicin molecule facilitates the binding of subsequent molecules) to noncooperative (independent binding) on reducing extracellular $\mathrm{pH}$. These effects of $\mathrm{pH}$ are unlikely to be due to changes in the degree of protonation of the capsaicin molecule itself, because with a $\mathrm{pK}_{\mathrm{a}}$ value of $10.10 \pm 0.05$ (Sirius PCA101 $\mathrm{pK}_{\mathrm{a}}-\log \mathrm{P}$ analyser) the change in the ratio of charged to uncharged capsaicin will be small over the $\mathrm{pH}$ range used here.

To determine whether modulation of extracellular $\mathrm{pH}$ had any effect on maximal response, the currents elicited by $10 \mu \mathrm{M}$ capsaicin, from the cumulative $\log$ (concentration)response curves in Figure 2 were compared (Figure 3a). Although these data showed no significant overall trend in maximal current magnitude as a function of $\mathrm{pH}$ there was some suggestion of larger responses at the lower $\mathrm{pH}$ values, such as $\mathrm{pH} 6.5$, than at very high $\mathrm{pH}$ values. This possible trend could represent a real difference, but masked by variable desensitization between neurons or, simply sampling error when studying a population with very variable
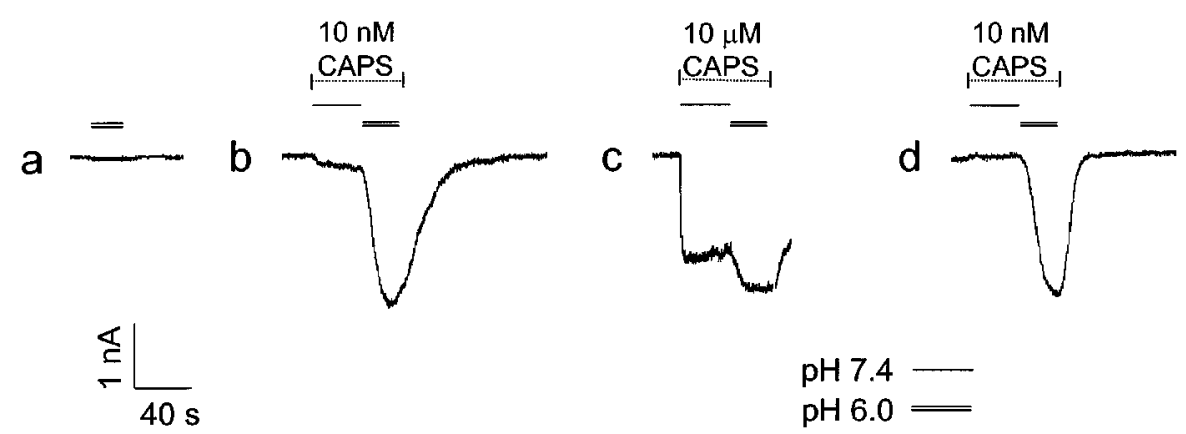

Figure 1 Potentiation of the response to capsaicin by low pH. DRG neuron was voltage clamped at $-60 \mathrm{mV}$ and capsaicin applied at pH 7.4 (single line) or pH 6.0 (double line) at either $10 \mathrm{~nm}$ (b, d) or $10 \mu \mathrm{M}$ (c) as indicated. (a) shows response to pH 6.0 solution without capsaicin. Inward current downwards, responses to low $\mathrm{pH}$ alone not subtracted. 

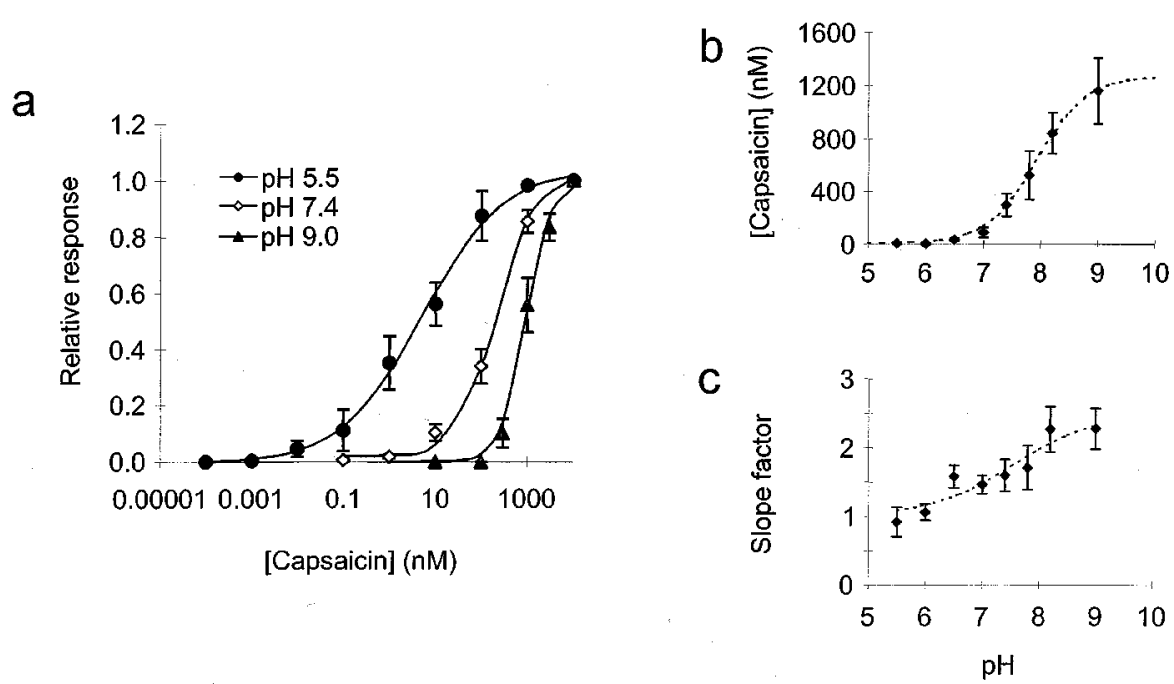

Figure 2 Effect of extracellular $\mathrm{pH}$ on the capsaicin $\log$ (concentration)-response curve. (a) $\log$ (concentration)-response curves for capsaicin recorded at $+60 \mathrm{mV}$ with extracellular $\mathrm{pH}$ of 5.5 (circles), 7.4 (open diamonds) and 9.0 (triangles). Curve fitted of form $\left[\mathrm{I}_{\min }-\mathrm{I}_{\max } /\left(1+\left(\mathrm{x} / \mathrm{x}_{0}\right)^{\mathrm{p}}\right]+\mathrm{I}_{\max }\right.$ (where; $\mathrm{I}_{\min }$ is the minimum current, $\mathrm{I}_{\max }$ the maximum, $\mathrm{x}_{0}$ the $\mathrm{x}$ value for half maximal response and $\mathrm{p}$ the apparent slope factor). Current was normalized to that elicited by $10 \mu \mathrm{M}$ capsaicin for each neuron. (b) Concentration of capsaicin for half maximal response at each of these $\mathrm{pH}$ values with additional such curves as a function of the extracellular $\mathrm{pH}$. Curve fitted based on model described in text constrained to a lower limit of $4.5 \pm 1.7 \mathrm{~nm}$ calculated from the mean data at $\mathrm{pH} 5.5$ and $\mathrm{pH} 6.0(n=18)$. Upper limit of $1270 \pm 160 \mathrm{nM}$ and $\mathrm{pK}_{\mathrm{a}}$ value of $7.9 \pm 0.2$ determined from best fit $(n=75)$. (c) Slope factors from the curves in (a) and additional such curves as a function of extracellular pH. Curve of same form as in (b) with limits of $1.1 \pm 0.2$ and $2.3 \pm 0.2$ and $\mathrm{pK}_{\mathrm{a}}$ value of $7.4 \pm 0.4$, determined from best fit $(n=75)$.
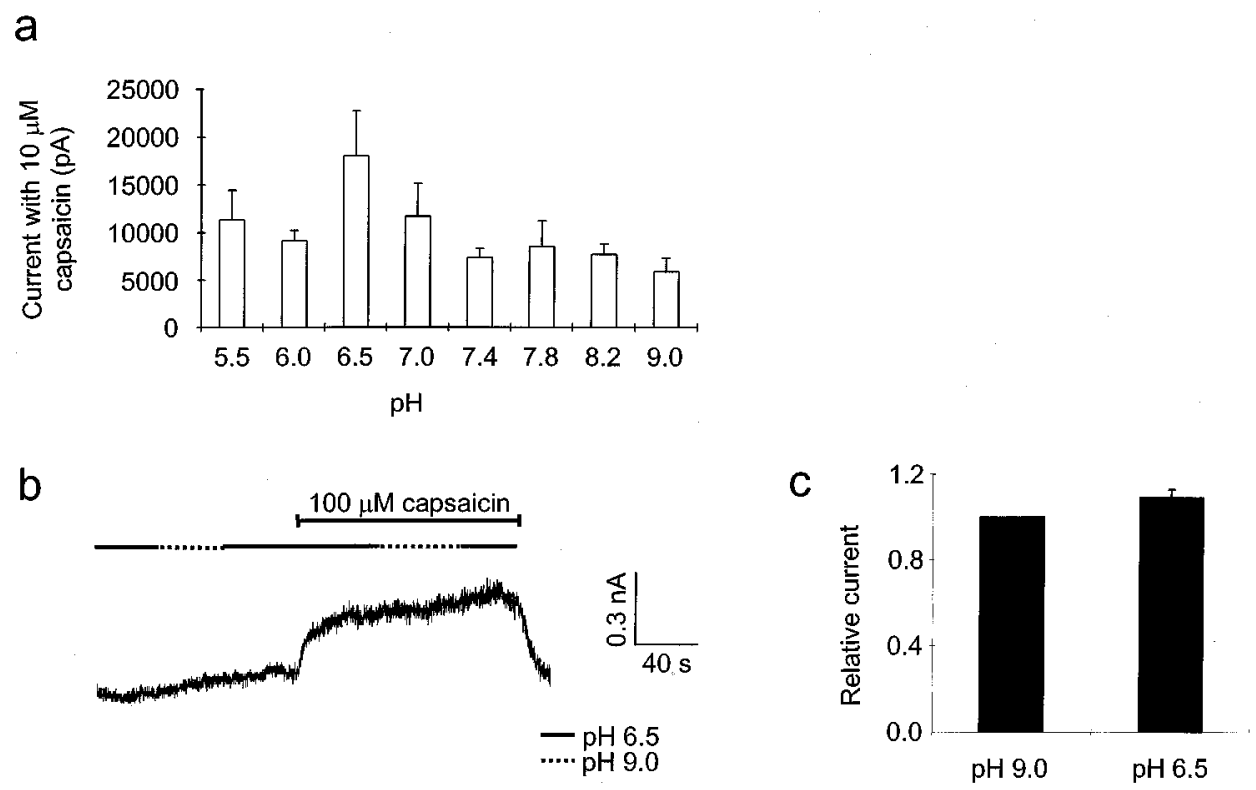

Figure 3 Effect of extracellular $\mathrm{pH}$ on the maximal capsaicin current. (a) Mean peak currents elicited by $10 \mu \mathrm{M}$ capsaicin from the data in Figure 2 as a function of $\mathrm{pH}$. (b) Effect of extracellular $\mathrm{pH}$ on the current elicited by $100 \mu \mathrm{M}$ capsaicin in a single neuron at $+40 \mathrm{mV}$. One hundred $\mu \mathrm{M}$ capsaicin was applied at $\mathrm{pH} 6.5$ then in the maintained presence of capsaicin extracellular $\mathrm{pH}$ increased to $\mathrm{pH} 9$, then returned to $\mathrm{pH} 6.5$ as shown. (pH order was reversed in half the neurons tested). Only one set of recordings was used from each neuron corresponding to the first application of capsaicin to that dish and only one neuron was used from each dish. Decreasing the extracellular $\mathrm{pH}$ had very little effect on the capsaicin elicited current. (c) Mean data from experiments such as that in (b) with any current elicited by the $\mathrm{pH}$ change alone subtracted, showing the relative size of the current at $\mathrm{pH} 6.5$ if that at $\mathrm{pH}$ 9.0 is $1(n=8)$.

sensitivities to capsaicin (see Bevan \& Winter, 1995). To differentiate between these possibilities a comparison was made between the potentiation seen at $\mathrm{pH} 6.5$ and 9.0 , with a very high concentration of capsaicin $(100 \mu \mathrm{M})$ in individual neurons not previously exposed to capsaicin. Figure $3 \mathrm{~b}$ shows a sample trace illustrating the type of protocol used, in which a neuron held at $+60 \mathrm{mV}$ in solution at $\mathrm{pH} 7.4$ was exposed to solutions of $\mathrm{pH} 6.5$ and 9.0, first in the absence of 
capsaicin, and then in the maintained presence of $100 \mu \mathrm{M}$ capsaicin. In this neuron, selected for its small current and small degree of desensitization (see below), there was virtually no effect of this change in $\mathrm{pH}$ in the absence of capsaicin and only a very small decrease in current on increasing the $\mathrm{pH}$ in the presence of capsaicin. Figure $3 \mathrm{c}$ shows the mean data from eight experiments of this type with variable order of $\mathrm{pH}$ presentation, where the average ratio of the current at $\mathrm{pH} 6.5$ as compared to that at $\mathrm{pH} 9.0$ was $1.09 \pm 0.04$. This value is not significantly different from 1 (paired $t$-test, $P=0.2$ $(n=8))$, indicating that the maximal response was not modified by changes in extracellular $\mathrm{pH}$ but that instead, the potentiation seen could be explained entirely by a shift in the position of the $\log$ (concentration)-response curve. Interestingly, following desensitization seen with subsequent applications of capsaicin to the same neuron, responses were more susceptible to the effects of $\mathrm{pH}$ change even at high capsaicin concentrations. This suggests that in this aspect at least, desensitization was equivalent to reducing the effective concentration of capsaicin.

In the next series of experiments the mechanism whereby the position of the capsaicin $\log$ (concentration)-response curves may be shifted by modifications in extracellular $\mathrm{pH}$ was addressed. To establish whether any changes in divalent cation permeability were involved, the magnitude of potentiation was compared in standard extracellular solution and in solution without added calcium or magnesium. As shown in Figure 4a there was an increase in the magnitude of the currents evoked by $10 \mathrm{nM}$ capsaicin at both $\mathrm{pH} 7.4$ and pH 6.0 on removing divalent cations (Docherty et al., 1996), but no significant effect on the actual degree of potentiation of the response (Figure $4 \mathrm{~b}$ ). This finding indicates that no part of the potentiation described above can be explained by a change in divalent cation permeability or by displacement of fixed charge contributed by divalent cations.

To investigate more closely the site of action of protons the effects of modifying internal $\mathrm{pH}$ were compared with those seen with changes in extracellular $\mathrm{pH}$. Figure 5 shows the current obtained on extracellular application of a low concentration $(10 \mathrm{nM})$ of capsaicin at $\mathrm{pH} 7.4$ (dark bars) or pH 6.0 (open bars), to neurons with one of three different internal solutions, standard internal solution at $\mathrm{pH} 7.4$ buffered with $10 \mathrm{mM}$ HEPES (left), solution at $\mathrm{pH} 7.4$ with
$40 \mathrm{mM}$ HEPES (middle) or reduced $\mathrm{pH}$ solution, pH 6.0 with $40 \mathrm{~mm}$ MES (right). Although there was a small decrease in the current elicited with extracellular $\mathrm{pH} 7.4$ on decreasing intracellular $\mathrm{pH}$, the large potentiated current seen at extracellular $\mathrm{pH} 6.0$ was not significantly different between the three groups $(P>0.9$, ANOVA). If the site responsible for potentiation were intracellular or close to the intracellular face of the membrane, then changing intracellular $\mathrm{pH}$ would be expected to have a greater effect than changing the extracellular $\mathrm{pH}$. In contrast, these results suggest that the site responsible for capsaicin potentiation is more accessible from the extracellular than the intracellular side of the membrane.

To investigate whether the site could be within the membrane electrical field the dependence of potentiation on voltage was examined. Figure $6 \mathrm{a}$ shows the outwardly rectifying current voltage relationships elicited at $\mathrm{pH} 7.4$ and $\mathrm{pH} 7.0$ by a concentration of capsaicin chosen to be sub maximal at both $\mathrm{pH}$ values for each neuron, (either 50 or $100 \mathrm{nM}$ in each case). Current was potentiated at all voltages.

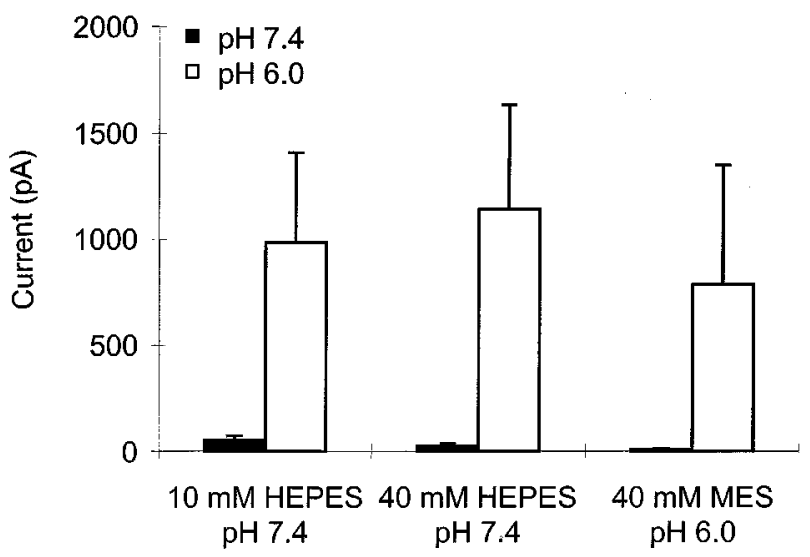

Figure 5 Effect of intracellular $\mathrm{pH}$ on the response to capsaicin. Current elicited by neurons held at $-60 \mathrm{mV}$ with internal $\mathrm{pH} 7.4$ (buffered with either 10 or $40 \mathrm{~mm}$ HEPES) or $\mathrm{pH} 6.0$ (buffered with $40 \mathrm{~mm}$ MES) to external application of $10 \mathrm{~nm}$ capsaicin at $\mathrm{pH} 7.4$ (filled bars) or $\mathrm{pH} 6.0$ (open bars) $(n=8,9,9)$. Series resistance $\leqslant 8 \mathrm{M} \Omega, \geqslant 5 \mathrm{~min}$ equilibration period after reaching whole-cell configuration before recording.
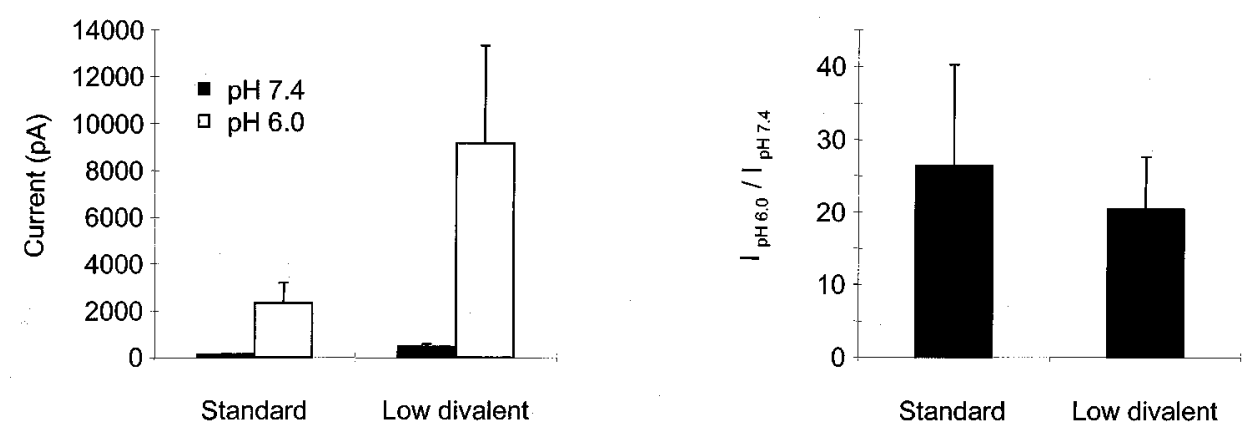

Figure 4 Effect of divalent cations on the potentiation of the capsaicin response. (a) Mean current elicited at $-60 \mathrm{mV}$ on application of $10 \mathrm{~nm}$ capsaicin at $\mathrm{pH} 7.4$ (filled bars) or $\mathrm{pH} 6.0$ (open bars) in standard or divalent solution as indicated. Currents elicited by $\mathrm{pH}$ alone were subtracted. (b) Current at $\mathrm{pH}$ 6.0/current at $\mathrm{pH} 7.4$ for each neuron in the two solutions $(n=11$ and 8 respectively). 
In Figure $6 \mathrm{~b}$ the relative potentiation, i.e. the current evoked at $\mathrm{pH} 7.0$ as a function of that at $\mathrm{pH} 7.4$ normalized to the ratio at $-100 \mathrm{mV}$ for each neuron is plotted as a function of voltage. There was no significant difference in this ratio as a function of voltage indicating that potentiation was not voltage dependent. This implies that the site of action is not within the membrane electrical field and therefore more likely to be on some extracellular region of the protein. This finding also implies that this site is likely to be remote from the capsaicin binding site which has recently been reported to be intracellular (Jung et al., 1999).

The absence of effect of reducing extracellular $\mathrm{pH}$ on the maximal response to capsaicin (Figure 3) suggests that the reduction in $\mathrm{pH}$ may affect open channel probability rather than to increase single channel conductance. This question was addressed directly by making recordings at the single channel level. In excised outside-out membrane patches, application of capsaicin to the extracellular side of the membrane elicited channel activity (Forbes \& Bevan, 1987; Oh et al., 1996). At a constant concentration of capsaicin, reducing $\mathrm{pH}$ from 8.5 to 5.5 led to a dramatic increase in the channel activity elicited and the number of open channels (Figure 7a), corresponding to an increase in channel open probability, assuming a constant total channel population in the patch, of over 20 times. No channel activity was elicited by the $\mathrm{pH}$ change alone in this experiment (data not shown) and recordings where 'background' channel activity was apparent at the $\mathrm{pH}$ value under study were not included in the analysis. The increase in channel activity was particularly marked (15 fold) with the decrease in $\mathrm{pH}$ from 8.5 to 7.4 which corresponds to the region of maximum $\mathrm{pH}$ dependence of the $\mathrm{EC}_{50}$ and apparent slope factors seen with whole-cell recordings (Figure 2). Figure $7 \mathrm{~b}$ shows current recordings with capsaicin elicited channel activity at a range of membrane potentials at extracellular $\mathrm{pH} 7.4$ and $\mathrm{pH} 5.5$ respectively. It is apparent that this figure and the single channel current-voltage relationship shown in Figure $7 \mathrm{c}$ containing data from five patches that the single channel conductance was not significantly modified by changes in extracellular $\mathrm{pH}$. Although there was no significant difference in single channel conductance which was, $91 \pm 11 \mathrm{pS}$ and
$35 \pm 2 \mathrm{pS}$ at $+60 \mathrm{mV}$ and $-60 \mathrm{mV}$ respectively at physiological $\mathrm{pH}$ and $81 \pm 11 \mathrm{pS}$ and $32 \pm 1 \mathrm{pS}$ at reduced $\mathrm{pH}$, there was a trend towards reduced conductance at low $\mathrm{pH}$ as recently reported by Baumann \& Martenson (2000).

Open time distributions were constructed from excised outside-out patches held at +60 to $+80 \mathrm{mV}$ with an external $\mathrm{pH}$ of either $8.5,7.4$ or low $\mathrm{pH}(\mathrm{pH} 5.5-6.5)$. In cases where multi-channel patches were used data were only included from periods of openings from baseline to the single open channel level. Figure 8a shows typical open time distributions for $\mathrm{pH} 8.5$ and 7.4, which were best fitted by two exponentials with a faster and a slower time constant respectively. Double exponential fits to open time distributions have been reported previously for the vanilloid receptor in rat DRG neurons (Oh et al., 1996) although a single exponential was found to best fit the open time distribution for the cloned VR1 receptor (Tominaga et al., 1998). In some of the single channel experiments data were filtered at $2 \mathrm{KHz}$ which limited the resolution of the brief events. For this reason analysis of measurements has been restricted to the second, slower component of the open time distributions. Mean values for the constant as a function of $\mathrm{pH}$ (Figure $8 \mathrm{~b}$ ) revealed no significant change with $\mathrm{pH}$ (ANOVA, $P>0.2$ ), with values of $3.1 \pm 0.8 \mathrm{~ms}(n=6, \mathrm{pH} 8.5), 4.2 \pm 1.2 \mathrm{~ms}(n=9$, $\mathrm{pH} 7.4)$ and $3.8 \pm 0.7 \mathrm{~ms}(\mathrm{pH} 5.5-6.5)$.

\section{Discussion}

\section{Mechanism of action}

The data presented here demonstrate a modulatory role for protons in setting the affinity of the native vanilloid receptor in adult rat DRG neurons for capsaicin without changing the maximal response or single channel conductance. This is clearly an important mechanism from the scale of the shifts seen, 200-300 fold over the full $\mathrm{pH}$ range studied here $(\mathrm{pH}$ $5.5-\mathrm{pH} 9$ ) and some $8-9$ fold over the more physiological range of $\mathrm{pH} 7.4$ to $\mathrm{pH} 6.5$. This latter shift compares with values of 2-6 fold seen for the cloned rat and human VR1 receptors over this $\mathrm{pH}$ range (Tominaga et al., 1998; Smart et
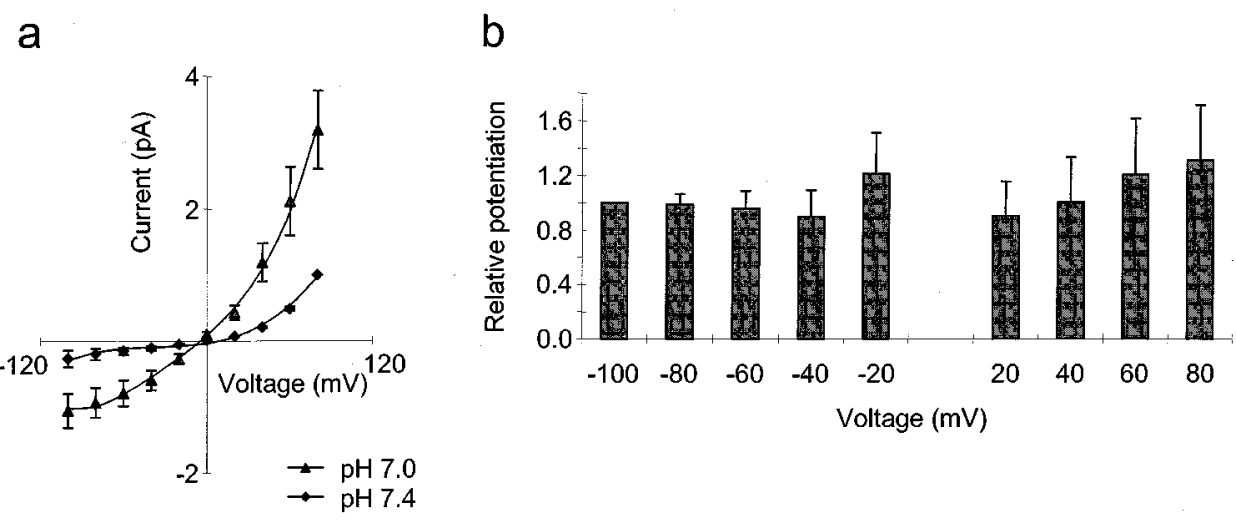

Figure 6 Voltage dependency of the potentiation of the capsaicin response by extracellular protons. (a) Current-voltage relationships at extracellular $\mathrm{pH} 7.4$ (diamonds) and 7.0 (triangles) with subthreshold concentration of capsaicin, either 50 or $100 \mathrm{nM}$ for each neuron. Current normalized to that at $+80 \mathrm{mV}$ and $\mathrm{pH} 7.4$ for each neuron. Responses to application of pH in the absence of capsaicin subtracted $(n=7)$. (b) Relative potentiation (current pH 7.0/current pH 7.4) as a function of voltage, normalized to that at $-100 \mathrm{mV}$ for each neuron $(n=7)$. 

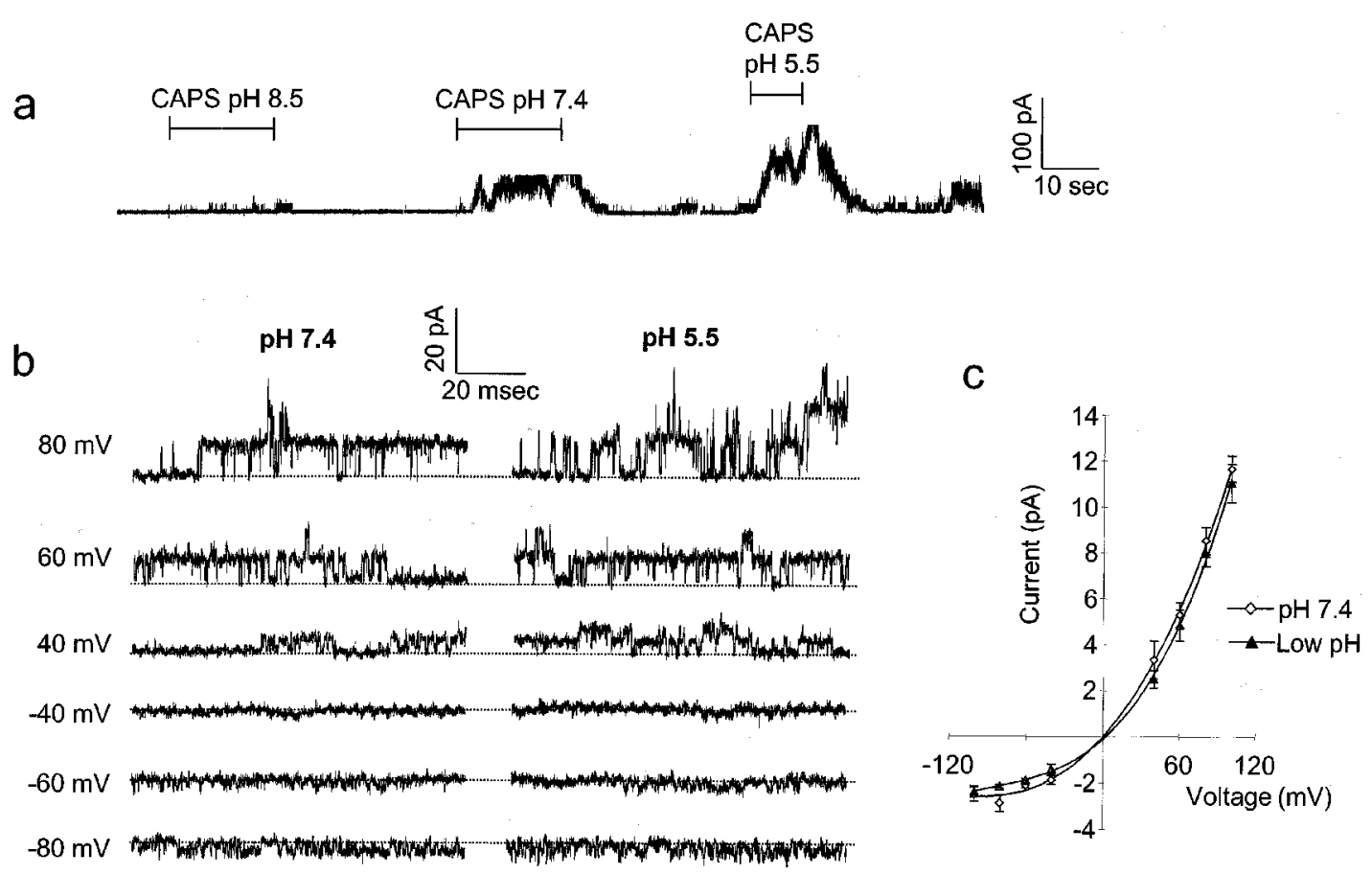

Figure 7 Effects of $\mathrm{pH}$ on the response to capsaicin at the single channel level. (a) Current elicited by outside-out patch at $+80 \mathrm{mV}$ on application of $10 \mu \mathrm{M}$ capsaicin at $\mathrm{pH} 8.5, \mathrm{pH} 7.4$ and $\mathrm{pH} 5.5$ as indicated. Filtered at $2 \mathrm{kHz}$. (b) Same patch as in (a) showing single channel activity at a range of potentials. No activity was seen in this patch on application of the $\mathrm{pH}$ solutions alone. (c) Mean single channel currrent-voltage relationship, combined data from five patches at $\mathrm{pH} 7.4$ (open diamonds) and reduced $\mathrm{pH}$ (filled triangles).

(a)

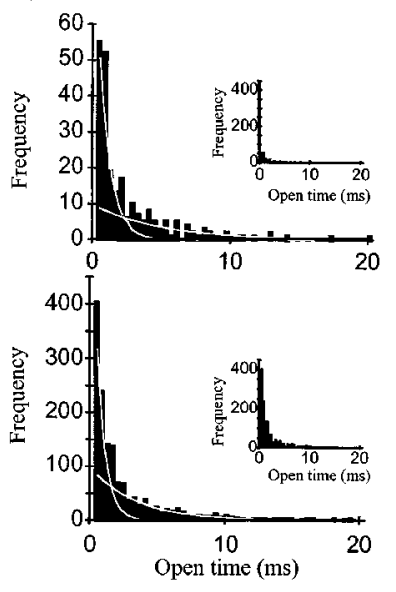

(b)

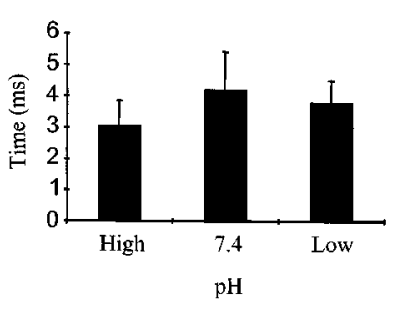

Figure 8 The effect of extracellular $\mathrm{pH}$ on mean channel open times. (a) Mean open time distributions of single channel activity in an outside-out patch at $+80 \mathrm{mV}$ with extracellular $\mathrm{pH} 8.5$ (upper) and $\mathrm{pH} 7.4$ (lower) each fitted with two exponentials. Inserts show data on the same scale to allow easier comparison of the relative frequencies. (b) Mean values for slower of these exponentials from $6-9$ patches as a function of $\mathrm{pH}$.

al., 2000). Our analysis of the dependence of $\mathrm{EC}_{50}$ values and slope factors on $\mathrm{pH}$ indicates that the relationships can be fitted by a sigmoidal curve with a mid-point at $\mathrm{pH}$ 7.4-7.9. These values are similar to the mid-point of $\sim \mathrm{pH} 7$ recently reported for the low $\mathrm{pH}$-induced potentiation of noxious heat responses of the rat cloned wild-type VR1 (Jordt et al., 2000). In contrast low $\mathrm{pH}$ solutions have been reported to have no effect on the response of rat cloned VR1 to another activator, anandamide (Smart et al., 2000). This finding suggests that $\mathrm{pH}$ modulation of VR1 activity may depend on the type of agonist.

Jordt et al. (2000) identified a glutamate residue (E600) thought to be located in the region that links the extracellular domain of the fifth transmembrane spanning region to the putative pore forming loop. Site directed mutagenesis showed that this residue is particularly important for potentiation of the heat responses. Replacement of glutamate with neutral or positively charged residues potentiated the current responses to heat and resulted in a reduction or loss of $\mathrm{pH}$ modulation of the evoked heat responses. Such amino acid changes also shifted the $\log$ (concentration)-response curves for capsaicin to lower concentrations, although the authors did not report whether the shifts were associated with any change in $\mathrm{pH}$ modulation of the capsaicin-evoked responses.

In the current study potentiation of the capsaicin response at low $\mathrm{pH}$ was not associated with any increase in the amplitude of the maximum response. This finding contrasts with a recent report that acidification from $\mathrm{pH} 8.0$ to $\mathrm{pH} 6.0$ is associated with a greater than 3 fold increase in the maximal capsaicin-evoked current response of human cloned VR1 expressed in Xenopus oocytes (Hayes et al., 2000). The reasons for this difference are unclear although they may be associated with either a species difference or the cellular environments of the native and cloned receptors.

A shift in the $\log$ (concentration)-response curve with constant maximal response could be described by assuming 
the conversion of individual receptors from a low affinity, unprotonated state at high $\mathrm{pH}$ values to a higher affinity, protonated state, on reducing $\mathrm{pH}$. The population response at any given $\mathrm{pH}$ value would then reflect the ratio of the numbers of receptors in the two states. The $\mathrm{pH}$ dependence of the shift in the apparent half maximal effect and slope factors are both consistent with this interpretation if the proton(s) interact(s) with a site, or sites, with $\mathrm{pK}_{\mathrm{a}}$ value of 7.4-7.9. This simple model is shown in scheme 1 with two pathways representing the protonated and non-protonated states of the receptor. It is unknown how many subunits make up each capsaicin receptor or how many capsaicin molecules are required to bind for activation. Hill coefficients (slope factors) of 1.7-2.2 (Vlachova \& Vyklicky, 1993; Koplas et al., 1997 and Figure 2a) for capsaicin interaction at physiological $\mathrm{pH}$, suggest at least two capsaicin molecules are involved. This finding suggests the involvement of at least two subunits but from comparison with potassium channels or nicotinic receptors for example, (e.g. Popot \& Changeux, 1984; Mackinnon, 1991), an overall composition of four or more subunits may occur. The model in Scheme 1 considers the simplest case and shows the sequential binding of two capsaicin molecules whilst acknowledging that this may be an over simplification and that additional steps could be added. Activation of the receptor by protons alone has been omitted from the model for clarity.

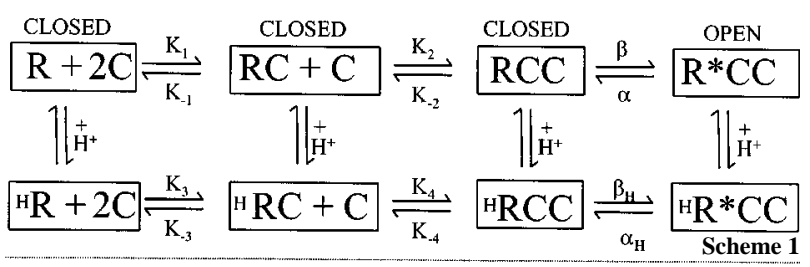

$\mathrm{K}_{1}$ to $\mathrm{K}_{4}$ are rate constants for capsaicin binding and $\mathrm{K}_{-1}$ to $\mathrm{K}_{-4}$ for unbinding. $\beta$ and $\alpha$ (or $\beta_{\mathrm{H}}$ and $\alpha_{\mathrm{H}}$ ) are rate constants for the conversion of the liganded receptor between the open and closed states. The reduction in cooperativity seen on reducing extracellular $\mathrm{pH}$ could imply the loss of one of the steps indicated in the lower pathway, or simply an increase in the rate constant such that that step is no longer limiting. Since it is not possible to determine from these data which of these two situations is occurring an equivalent number of steps have been included in both pathways.

The single channel results showing that conductance is unchanged but that open probability is increased on reducing extracellular $\mathrm{pH}$ are consistent with this model in that they favour a change in the conversion rate between states rather than the development of a new state. From the analysis of the single channel open times the values $\alpha$ and $\alpha_{\mathrm{H}}$, the rate constants for transition from the open to closed state of the channel, appear to be equal. This implies that changes in the binding rate constants or $\beta$ values must mediate the increase in open channel probability.

Whilst this model is consistent with the majority of the data presented here it may be an oversimplification. For example protons may interact with more than one site on the receptor. Although we have fitted the relationships between $\mathrm{pH}$ and either $\mathrm{EC}_{50}$ values or slope factors with single sigmoidal curves, close inspection of the slope factor data suggests that the $\mathrm{pH}$ dependence of the slope factors (Figure 2c) could be fitted by a double sigmoidal function with $\mathrm{pK}_{\mathrm{a}}$ values of about pH 6 and 8. Support for the contribution of a single site is provided by the identification of the importance of the glutamate residue (E600) for potentiation of noxious heat responses in site directed mutagenesis studies (Jordt et al., 2000). Nevertheless we cannot rule out at present that other residues may have a role in proton-induced potentiation.

It is possible that $\mathrm{pH}$ modulation of VR1 involves changes in both chemical sensitivity and thermal thresholds and that our experiments have monitored the net agonism of VR1 induced by capsaicin at a lowered temperature threshold. In the present study temperature in individual experiments was steady, despite some day to day variations, and low $\mathrm{pH}$ alone often had no significant agonist effect at the experimental temperatures used (see e.g. Figure 1). We cannot rule out the possibility that capsaicin also modulates temperature threshold. It would be interesting to extend the present findings to study the effects of temperature on $\mathrm{pH}$ modulation of chemical sensitivity, but such a study is beyond the scope of the present investigation. It is hoped that this initial 'simple' model will serve as a valuable starting point from which to study interactions at this receptor further and for comparison of the native receptor with the cloned VR1.

\section{Site of proton action}

All of the data presented here argue against the site or sites of proton action mediating potentiation being within the channel pore or membrane electrical field. If the proton(s) acted within the membrane electrical field a voltage dependence would be expected which was not seen. Similarly, the absence of any interaction with divalent cations or effect on the single channel conductance and hence maximal response support this view. The larger effect of extracellular than intracellular $\mathrm{pH}$ change suggest that the site(s) is(are) on an extracellular region of the protein. These characteristics are consistent with the identification of a glutamate residue (E600), which is extracellular and not part of the putative pore region, as an important modulatory site for protons. This modulatory site appears to differ from the extracellular site responsible for proton activation of the VR1 (Jung et al., 1999; Tominaga et al., 1998), which has been identified, at least in part, as another glutamate residue (E648). Both sites appear to be remote from the proposed intracellular capsaicin site (Jung et al., 1999) and imply that the potentiating effects of $\mathrm{pH}$ are likely to be mediated via an allosteric change in the receptor rather than a direct interaction of a proton with the capsaicin binding site. The identification of glutamate residues as important mediators of proton activation and potentiation of VR1 highlights the differences between the $\mathrm{pK}_{\mathrm{a}}$ values for the side chain of free glutamic acid $(\mathrm{pH}$ 4.28) and the observed $\mathrm{pH}$ for half maximal potentiation of capsaicin or noxious heat responses (pH 7-8) and activation by low $\mathrm{pH}(\mathrm{pH} 5.3-5.8$; Bevan \& Yeats, 1991; Jordt et al., 2000). Such differences in the titration of the side chains of amino acids in solution and when in the complex chemical microenvironment of proteins are well known and have been reported for other ion channels including L-type calcium channels (see Chen \& Tsien, 1997) and cyclic nucleotide gated channels (Morrill \& MacKinnon, 1999). 


\section{Physiological implications}

The vanilloid receptor has also been shown to be sensitive not only to capsaicin and protons but also to both heat (Tominaga et al., 1998) and the endogenous cannabinoid, anandamide (Zygmunt et al., 1999; Smart et al., 2000). Reduction in $\mathrm{pH}$ has been demonstrated to potentiate the response of VR1 to heat (Tominaga et al., 1998) although not to anandamide (Smart et al., 2000). It is unclear why this should be the case and whether the same is true of the native receptor.

The potentiation of the response to heat could be very important physiologically, for, as suggested by Vyklicky et al. (1999) protons may function to decrease the threshold for the heat response such that a previously ineffective temperature becomes stimulatory and hence painful.

A reduction in $\mathrm{pH}$ has also been shown to potentiate the response of $\mathrm{P} 2 \mathrm{X}_{2}$ containing receptors to ATP (King et al., 1996; Li et al., 1996; 1997; Stoop et al., 1997). This potentiation shows similarities to that seen here for capsaicin except that cooperativity is not affected by changes in $\mathrm{pH}$. Like the capsaicin response this potentiation of the $\mathrm{P}_{2} \mathrm{X}_{2}$ containing receptor is voltage independent, involves a site with $\mathrm{pK}_{\mathrm{a}}$ value of 7.6 (Li et al., 1996) and the interaction of a single effector and could involve a similar mechanism.

\section{References}

BAUMANN, T.K. \& MARTENSON, E. (2000). Extracellular protons both increase the activity and reduce the conductance of capsaicin-gated channels. J. Neurosci., 20, 1-5.

BEVAN, S. \& DOCHERTY, R.J. (1993). Cellular mechanisms of the action of capsaicin. In Capsaicin in the study of pain. ed. Wood, J. Chapter 2, pp. $27-44$. Academic Press.

BEVAN, S., FORBES, C.A. \& WINTER, J. (1993). Protons and capsaicin activate the same ion channels in rat isolated dorsal root ganglion cells. J. Physiol., 459, 401P.

BEVAN, S. \& WINTER, J. (1995). Nerve growth factor (NGF) differentially regulates the chemosensitivity of adult rat cultured sensory neurons. J. Neurosci., 15, $4918-4926$.

BEVAN, S. \& YEATS, J. (1991). Protons activate a cation conductance in a sub-population of rat dorsal root ganglion neurons. $J$. Physiol., 433, $145-161$.

CATERINA, M.J., LEFFLER, A., MALMBERG, A.B., MARTIN, W.J. TRAFTON, J., PETERSON-ZEITZ, K.R., KOLTZENBURG, M., BASBAUM, A.I. \& JULIUS, D. (2000). Impaired nociception and pain sensation in mice lacking the capsaicin receptor. Science, 288, $306-313$.

CATERINA, M.J., SCHUMACHER, M.A., TOMINAGA, M., ROSEN, T.A., LEVINE, J.D. \& JULIUS, D. (1997). The capsaicin receptor: a heat-activated ion channel in the pain pathway. Nature, 389, $816-824$

CHEN, X.H. \& TSIEN, R.W. (1997). Aspartate substitutions establish the concerted action of P-region glutamates in repeats I and III in forming the protonation site of L-type $\mathrm{Ca}^{2+}$ channels. J. Biol. Chem., 272, 30002-30008.

DAVIS, J.B., GRAY, J., GUNTHORPE, M.J., HATCHER, J.P., DAVEY, P.T., OVEREND, P., HARRIES, M.H., LATCHMAN, J., CLAMPHAM, C., ATKINSON, K., HUGHES, S.A., RANCE, K., GRAU, E. HARPER, A.J., PUGH, P.L., ROGERS, D.C., BINGHAM, S., RANDALL, A. \& SHEARDOWN, S.A. (2000). Vanilloid receptor1 is essential for inflammatory thermal hyperalgesia. Nature, $\mathbf{4 0 5}$, $183-187$.

DOCHERTY, R.J., YEATS, J.C., BEVAN, S. \& BODDEKE, H.W.G.M (1996). Inhibition of calcineurin inhibits the desensitization of capsaicin-evoked currents in cultured dorsal root ganglion neurons from adult rats. Pflugers Archiv., 431, 828-837.
It is clear from the polymodal nature of the vanilloid receptor that interaction between its different activators is an important part of its function. Here, by studying one of these pairs of interactions we have developed a model in which on reducing extracellular $\mathrm{pH}$ the vanilloid receptor in rat DRG neurons undergoes an allosteric change, shifting it from a low to high affinity state coincident with a loss of cooperativity. This effect, presumed to involve proton interaction is voltage independent indicating a site or sites of action outside the membrane electrical field. The absence of potentiation seen on reducing intracellular $\mathrm{pH}$ points to an extracellular site. The increase in channel open probability and the reduction in cooperativity suggest a facilitation in the transition between the open and closed states and possibly a reduction in the number of capsaicin molecules required for activation. It is hoped that this model should provide a useful starting point from which to explore additional interactions at this receptor.

We wish to thank Hendrikus Eggelte and David Bentley for measuring the $\mathrm{pK}_{\mathrm{a}}$ of capsaicin, Prof Humphrey Rang for helpful comments and discussion on the manuscript and Dr Alison Reeve for some of the single channel recordings.

FENWICK, E.M., MARTY, A. \& NEHER, E. (1982). Sodium and calcium channels in bovine chromaffin cells. J. Physiol., 331, $599-635$.

FORBES, C.A. \& BEVAN, S. (1987). Single channels activated by capsaicin in patches of membrane from adult rat sensory neurons in culture. Neurosci. Lett. Suppl., 32, S3.

HAYES, P., MEADOWS, H.J., GUNTHORPE, M.J., HARIES, M.H., DUCKWORTH, D.M., CAIRNS, W., HARRISON, D.C., CLARKE, C.E., ELlingtON, K., PRINJHA, R.K., BARTON, A.J.L., MEDHURST, A.D., SMITH, G.D., TOPP, S., MURDOCK, P., SANGER, G.J., TERRETT, J., JENKINS, O., BENHAM, C.D., RANDALL, A.D., GLOGER, I.S. \& DAVIS, J.B. (2000). Cloning and functional expression of a human orthologue of rat vanilloid receptor-1. Pain, 88, 205-215

HELliWEll, R.J.A., MCLATCHIE, L.M., ClARKE, M., WINTER, J., BEVAN, S. \& MCINTYRE, P. (1998). Capsaicin sensitivity is associated with the expression of the vanilloid (capsaicin) receptor (VR1) mRNA in adult rat sensory ganglia. Neurosci. Lett., 250, $177-180$.

JACOBUS, W.E., TAYLOR, G.J., HOLLIS, D.P. \& NUNNALLY, R.L. (1977). Phosphorus nuclear magnetic resonance of perfused working rat hearts. Nature, 265, 756-758.

JORDT, S.-V., TOMINAGA, M. \& JULIUS, D. (2000). Acid potentiation of the capsaicin receptor determined by a key extracellular site. Proc. Natl. Acad. Sci. U.S.A., 97, 8134-8139.

JUNG, J., HWANG, S.W., KWAK, J., LEE, S.-L., KANG, C.-J., KIM, W.B., DONGHEE, K. \& OH, U. (1999). Capsaicin binds to the intracellular domain of the capsaicin-activated ion channel. $J$. Neurosci., 19, 529-538.

KING, B., ZIGANSHINA, L.E., PINTOR, J. \& BURNSTOCK, G. (1996). Full sensitivity of $\mathrm{P}_{2 \mathrm{X} 2}$ purinoceptor to ATP revealed by changing extracellular pH. Br. J. Pharmacol., 117, 1371-1373.

KOPLAS, P.A., ROSENBERG, R.L. \& OXFORD, G.S. (1997). The Role of Calcium in the desensitization of Capsaicin Responses in Rat Dorsal Root Ganglion Neurons. J. Neurosci., 17, 3525-3537.

KRESS, M., FETZER, S., REEH, P.W. \& VYKLICKY, L. (1996). Low pH facilitates capsaicin responses in isolated sensory neurons of the rat. Neurosci. Lett., 211, 5-8. 
LI, C., PEOPLES, R.W. \& WEIGHT, F.W. (1996). Proton potentiation of ATP-gated ion channel responses to ATP and $\mathrm{Zn}^{2+}$ in rat nodose ganglion neurons. J. Neurophysiol., 76, $3048-3058$.

LI, C., PEOPLES, R.W. \& WEIGHT, F.F. (1997). Enhancement of ATPactivated current by protons in dorsal root ganglion neurons. Pflugers Archiv., 433, 446-454.

LINDAHL, O. (1962). Pain: a chemical explanation. Acta Rheumatologica Scandinavica, 8, 161-169.

LINGUEGLIS, E., DE WEILLE, J.R., BASSILANA, F., HEURTEAUX, C., SAKAI, H., WALDMAN, R. \& LAZDUNSKI, M. (1997). A modulatory subunit of acid sensing ion channels in brain and dorsal root ganglion cells. J. Biol. Chem., 272, 29778-29783.

LIU, L. \& SIMON, S.A. (1996). Capsaicin-induced currents with distinct desensitisation and $\mathrm{Ca}^{2+}$ dependence in rat trigeminal ganglion cells. J. Neurophysiol., 75, $1503-1514$.

MACKINNON, R. (1991). Determination of the subunit stoichiometry of a voltage-activated potassium channel. Nature, 350, 232-235.

MARTENSON, M.E., INGRAM, S.L. \& BAUMANN, T.K. (1994). Potentiation of rabbit trigeminal responses to capsaicin in a low $\mathrm{pH}$ environment. Brain Research, 651, 143-147.

MCLATCHIE, L.M. \& BEVAN, S. (1998a). Protons affect the affinity and apparent cooperativity of the interaction between capsaicin and the vanilloid receptor in adult rat isolated DRG neurons. $J$. Physiol., 513, 129P.

MCLATCHIE, L.M. \& BEVAN, S. (1998b). Effects of protons on the affinity and cooperativity of capsaicin interaction with the vanilloid receptor in rat DRG neurons. Soc. Neurosci. Abstr., 721.6.

MORRILL, J.A. \& MACKINNON, R. (1999). Isolation of a single carboxyl-carboxylate proton binding site in the pore of a cyclic nucleotide-gated channel. J. General Physiol., 114, 71-83.

OH, U., HWANG, S.W. \& KIM, D. (1996). Capsaicin activates a nonselective cation channel in cultured neonatal rat dorsal root ganglion neurons. J. Neurosci., 16, 1659-1667.

PETERSEN, M. \& LAMOTTE, R.H. (1993). Effect of protons on the inward current evoked by capsaicin in isolated dorsal root ganglion cells. Pain, 54, $37-42$.

POPOT, J.-L. \& CHANGEUX, J.-P. (1984). Nicotinic receptor of acetylcholine: structure of an oligomeric integral membrane protein. Physiological Reviews, 64, $1162-1239$.

SMART, D., GUNTHORPE, M.J., KJERMAN, J.C., NASIR, S., GRAY, J., MUIR, A.I., CHAMBERS, J.K., RANDALL, A.D. \& DAVIS, J.B. (2000). The endogenous lipid anadamide is a full agonist at the human vanilloid receptor (hVR1). Br. J. Pharmacol., 129, $227-$ 230.
STEEN, K.H. \& REEH, P.W. (1993). Sustained graded pain and hyperalgesia from harmless experiments tissue acidosis in human skin. Neurosci. Lett., 154, 113-116.

STEEN, K.H., STEEN, A.E. \& REEH, P.W. (1995). A dominant role of acid $\mathrm{pH}$ in inflammatory excitation and sensitization of nociception in rat skin in vitro. J. Neurosci., 15, 3982-3989.

STEEN, K.H., REEH, P.W., ANTON, F. \& HANDWERKER, H.O. (1992). Protons selectively induce lasting excitation to mechanical stimulation of nociceptors in rat skin, in vitro. J. Neurosci., 12, $86-95$.

STOOP, R., SUPRENANT, A. \& NORTH, R.A. (1997). Different sensitivities to $\mathrm{pH}$ of ATP-induced currents at four cloned P2X receptors. J. Neurophysiol., 78, $1837-1840$

TOMINAGA, M., CATERINA, M.J., MALMBERG, A.B., ROSEN, T.A. GILBERT, H., SKINNER, K., RAUMANN, B.E., BASBAUM, A.I. \& JULIUS, D. (1998). The cloned capsaicin receptor integrates multiple pain-producing stimuli. Neuron, 21, 531-543.

UCHIDA, Y. \& MURAO, S. (1975). Acid-induced excitation of afferent cardiac sympathetic nerve fibres. Am. J. Physiol., 228, 27-33.

VYKLICKY, L., VLACHOVA, V., VITASKOVA, Z., DITTERT, I., KABAT, M. \& ORKAND, R.K. (1999). Temperature coefficient of membrane currents induced by noxious heat in sensory neurons of the rat. J. Physiol., 517, 181-192.

VLACHOVA, V. \& VYKLICKY, L. (1993). Capsaicin-induced membrane currents in cultured sensory neurons of the rat. Physiological Research, 42, 301-311.

WALDMANN, R., CHAMPIGNY, G., BASSILANA, F., HEURTEAUX, C. \& LAZDUNSKI, M. (1997a). A proton-gated cation channel involved in acid-sensing. Nature, 386, 173-177.

WALDMANN, R., BASSILANA, F., WEILLE, J.-D., CHAMPIGNY, G., HEURTEAUX, C. \& LAZDUNSKI, M. (1997b). Molecular cloning of a non-inactivating proton-gated $\mathrm{Na}^{2+}$ channel specific for sensory neurons. J. Biol. Chem., 272, 20975-20978.

YEATS, J.C., DOCHERTY, R.J. \& BEVAN, S. (1992). Calciumdependent and independent desensitization of capsaicin-evoked responses in voltage-clamped adult dorsal root ganglion (DRG) neurons in culture. J. Physiol., 446, 390P.

ZYGMUNT, P.M., PETERSSON, J., ANDERSSON, D.A., CHUANG, H.H., SORGARD, M., MARZO, V., JULIUS, D. \& HOGESTATT, E.D (1999). Vanilloid receptors on sensory nerves mediate the vasodilator action of anandamide. Nature, 400, 452-457.

(Received April 26, 2000

Revised November 16, 2000 Accepted December 11, 2000) 